ции личности и жизненной активности в частности. На основе проведенного эмпирического исследования раскрыты особенности временной ориентации личности подросткового возраста и факторы, влияющие на формирование точности измерения времени.

Ключевые слова: психологическое время, временная ориентация, жизненная активность, особенности подросткового возраста, психическое состояние личности, типология акцентуаций характера.

N. Pogoril'ska, Ph. D., Assoc. Prof.,

Yu. Matsionova, student

Taras Shevchenko National University of Kyiv, Kyiv

\title{
FEATURES OF ADOLESCENTS TIME PERCEPTION IN THE CONTEXT OF THEIR LIVING ACTIVITY
}

The article defines the connection between the individual peculiarities of time perception and the levels of personal life activity. The results of the empirical study suggest that the diversity of levels in the perception of time in the adolescent psyche depends on a number of factors, including innate biological cycles $t$, ending with a complex subjective sense of time (in the context of age-related changes). Accordingly, it eliminates the contradiction between the uncertainties of the opposing time of the subject. Theoretical analysis of the factors that determine the perception of a teenager's personality provides an opportunity to make a prediction in social and psychological development in the context of accelerated social life. From the considered theories of understanding of time, the most comprehensive concept in the context of adolescent life activity is the definition of time as a directed value (vector), the unambiguous definition of which implies not only a system of units of measure (second, minute, hour, day, month, year, century), but and the constant starting point from which the account is maintained. The article made a comparative analysis of hysterical traits of the subjects with middle and high activity level of life, as well as the analysis of memories of adolescents with medium and high level of life activity. On the basis of the empirical research the features of time orientation of adolescence personality are revealed and factors that influence the formation of time measurement accuracy. The domestic and foreign theoretical approaches, empirical researches of concepts of the time orientation of the personality and vital activity in particular are analyzed. On the basis of the empirical research, features of the age orientation of the adolescent age and factors influencing the formation of the accuracy of time measurement are revealed.

Keywords: psychological time, time orientation, vital activity, peculiarities of adolescence, psychic state of personality, typology of character accentuations.

Bulletin of Taras Shevchenko National University of Kyiv. Series "Psychology". № 2(9), pp. 60-63 (2018) УДК 159.922.1:355

DOI: https://doi.org/10.17721/BSP.2018.2(9).15
ISSN 1728-3817

(C) Taras Shevchenko National University of Kyiv,

Publishing Center "Kyiv University", 2018

М. Прищепа, психолог Збройні Сили України

\section{ГЕНДЕРНІ ОСОБЛИВОСТІ ПЕРЕЖИВАННЯ ПСИХОТРАВМУЮЧИХ СИТУАЦІЙ ВІЙСЬКОВОСЛУЖБОВЦЯМИ В ХОДІ РЕСОЦІАЛІЗАЦІЇ В ПОСТТРАВМАТИЧНИЙ ПЕРІОД}

Присвячено аналізу відмінностей у сприйманні стресових і психотравмуючих ситуацій та їх впливу на особистісні зміни між чоловіками й жінками, які брали участь у бойових діях і які перебували поза зоною військового конфлікту в період ресоціалізації.

Ключові слова: військовослужбовець, посттравматичний стресовий розлад, психотравмуюча ситуація, стресостійкість, бойові дї.

Актуальність дослідження. У світі сьогоднішніх трагічних подій в Україні поряд із економічною кризою, військовими діями, окупацією Криму й Донбасу військами Російської Федерації, загостренням політичної ситуації, доволі актуальною темою сьогодення $€$ подолання психічних травм, стресових, гострих стресових та посттравматичних стресових розладів (ПТСР). Ураховуючи соціально-політичну ситуацію у країні, вплив на свідомість людей агресивного інформаційного чинника та наслідків бойових дій на території України гостро випливає проблема ресоціалізації військовослужбовців у посттравматичний період, а саме в період адаптації після повернення із зони бойових дій, переживання стресових станів, бойового стресу.

Аналіз останніх досліджень і публікацій. На сьогодні 3 гендерної проблематики опубліковано вже доволі багато наукових праць, які містять, переважно, переклади зарубіжних і вітчизняних класиків із фемінізму та гендерних досліджень, таких, як: М. Сігел, Д. Батлер, О. Бурчак, Л. Кобелянська, Р. Брайдотті, Т. де Лауретіс тощо.

Метою статті $є$ виявлення гендерних особливостей переживання психотравмуючих ситуацій у ході ресоціалізації в посттравматичний період.

Виклад основного матеріалу дослідження. На основі аналізу екстремальних, емоційно складних, критичних, кризових ситуацій було розроблено класифікацію рівнів психотравмуючих ситуацій, вивчення переживань у травмуючих ситуаціях різних рівнів такими дослідниками, як Е. Носенко, Ф. Василюк, О. Саннікова, І. Маноха, Г. Сельє, Т. Титаренко, Л. Сохань, Є. Головаха, В. Очеретяний та багатьма іншими. Водночас, не було охоплено дослідження бага- тьох інших проблем, таких, як: відмінність у сприйманні стресових і психотравмуючих ситуацій та їх вплив на особистісні зміни між чоловіками й жінками, які брали участь у бойових діях та які перебували поза зоною військового конфрлікту. Тому ми взяли за мету дослідити саме ці питання.

Традиційно травми розрізняють:

- за видом травмуючого фактора (людина, природа);

- за терміном дії травмуючого фактора (гострі, хронічні);

- за обставинами, за яких травма виникає (катастрофа, сім'я, спорт, воєнні дії тощо).

Щодо виявів реакцій на стрес, ураховуючі саме гендерний аспект, С. Бем у своїй монографії "Лінзи тендеру" (1993), розглядає поширену думку і віру, що відмінності в поведінці чоловіків і жінок, їхні соціальні позиції є наслідком біологічних, тобто статевих відмінностей.

Для успішної ресоціалізації військових у мирне життя потрібно дотримуватись ряду вимог. Сюди входить і вибір методів та технік психокорекційної роботи, які визначають враховуючи індивідуально-психологічні особливості кожного індивіда та головні завдання психологічної корекції:

- зниження емоційного напруження;

- відновлення функціонального стану організму;

- навчання основним методам психічної саморегуляції;

- підвищення особистісного адаптаційного потенціалу;

- відновлення моральних рис особистості військовослужбовців;

- фрормування конструктивного стереотипу поведінки, який би сприяв подальшим успіхам у професійній сфері та особистому житті;

- розвиток комунікативних здібностей і навичок. 
Успішність подолання наслідків психотравмуючого бойового стресу залежить від своєчасного їх виявлення у того чи іншого військовослужбовця [4].

У дослідженні, проведеному методом ПЕТ Мірко Діксічем (Mirko Diksic) з Університету Макджилл, було виявлено, що у чоловіків вироблення серотоніну в середньому на 52 \% вище, ніж у жінок. Ці дані говорять про більшу сприйнятливість психологічних стресорних ситуацій у жінок і про те, що ПТСР по-різному виявляється у жінок і чоловіків [3]. Тому у використанні заходів зі зниження емоційних переживань у військових жіночої й чоловічої статі також передбачається застосування різних програм реабілітації.

Розглядаючи психологічні особливості емоційних переживань військовослужбовців, необхідно враховувати гендерні особливості. У структурі особистості військових чоловіків і жінок спостерігаються відмінності: у жінок вищі показники соціальної пластичності, емоційності, соціальної емоційності, а у чоловіків - енергійності (здатності виконувати роботу за несприятливих умов - шуму, некомфортної температури тощо), пластичності та індивідуального темпу. При цьому соціальна енергійність і соціальний індивідуальний темп зі статтю не пов'язані.

Якщо говорити про прагнення до лідерства, домінантності, незалежності, то Е. Іглі зазначає, що чоловіки є інструментальними лідерами, а жінки - соціальними [2].

Згідно з іншими дослідженнями [5], незважаючи на відсутність відмінностей між чоловіками і жінками за загальним рівнем коефіцієнта емоційності, жінки виявляють більш високий рівень за міжособистісним показниками емоційного інтелекту (емоційності, міжособистісних стосунків, соціальної відповідальності). У чоловіків переважають внутрішньо особистісні показники (самоствердження, здатність відстоювати свої права), здібності до управління стресом (стресостійкість, контроль імпульсивності) і адаптованість (визначення правдоподібності, розв'язання проблем). Чоловіки, у свою чергу, виявляють більшу самоповагу, більш незалежні, краще справляються зі стресом, краще вирішують проблеми.

У жінок порівняно з чоловіками переважає розуміння емоцій. В іншому відмінності мають скоріше якісний, ніж кількісний характер. Чоловіки і жінки рівною мірою переживають ті чи інші події, демонструють ідентичні фізіологічні реакції. Однак вони по-різному, відповідно до своєї гендерної роллі, пояснюють причини емоцій [2].

Нами були проведені дослідження груп військовослужбовців чоловіків та жінок у 2015 та 2016 рр. на ймовірність виявів посттравматичного стресового розладу (ПТСР) у процесі ресоціалізації. Загальна кількості опитуваних у 2015 р. становить 45 осіб, із яких 22 жінки та 23 чоловіка. Вік опитуваних: чоловіки 23-54 роки, жінки 29-43 роки. У 2016 р. нами були опитані 41 військовослужбовець, із яких 22 жінки та 19 чоловіків. Вік опитуваних - чоловіки 25-50 років, жінки 22-45 років. Унаслідок об'єктивних причин неможливості опитати весь контингент військовослужбовців, який був досліджений у 2015 р., склад респондентів дещо різниться, але потрібно відмітити, що сам контингент цих опитаних виконував задачі, які є дуже подібними до задач, виконуваних попередньо опитаними. Тому ми візьмемо на себе сміливість і відповідальність порівнювати дані, отримані в попередньому дослідженні, із даними, отриманими у 2016 р.

У групу опитуваних входять військові медичні працівники Центрального клінічного медичного центру м. Вінниці: лікарі, медичні сестри, військовослужбовці в/ч A2656 та в/ч А1660 м. Вінниці (військова спеціальність "Зв'язківці"), в/ч А2215 м. Бориспіль (військова спеціальність "Льотчики"); а також військовослужбовці інших військових частин та спеціальностей. Усі опитувані чоловіки виконували військові завдання у зоні проведення АТО. Жінки не у повному складі перебували в зоні бойових дій.
Зазначимо, що у своїх дослідженнях ми зіткнулись із проблемою опитування серед військових. Не завжди людина, яка перебувала чи знаходилась тривалий час під впливом психотравмуючої ситуації, згодна пройти опитування й відповісти на ряд запитань. Тому розмір вибірки, кількість методик і питань, які в них містяться, $€$ невеликими. Але дослідження дало можливість підмітити ряд цікавих та цінних закономірностей, що в майбутньому може стати ґрунтом для продовження досліджень і виявлення інших відомостей та фактів. А також може сприяти розробленню програм реабілітації військовослужбовців, ураховуючи гендерний фактор, тип темпераменту та ряд інших властивостей.

Військові дії на території нашої країни мають неабиякий вплив на жінок-військовослужбовців. У ЗСУ наразі проходить службу близько 14,5 тис. жінок. Останні роки видались доволі напруженими, але ця категорія показала себе з найкращого боку. У деяких випадках саме завдяки жінці під силу виконати завдання, на яке не завжди достатньо сил чи можливостей у чоловіка. Жінки виявили себе в різних галузях: психологічна допомога в переважній більшості надається саме жінками; волонтерська діяльність - жінки без вагань відвідували місця ведення бойових дій; медицина - нарівні з чоловіками надавали допомогу пораненим саме жінки; снайпери, зв'язківці, журналісти та багато інших спеціальностей, якими займаються жінки на війні.

Підрозділи ЗСУ, які не виконують завдання в зоні проведення АТО, весь цей час також доволі напружено працювали. Одну з категорій опитуваних нами жінок становлять зв'язківці. Російська експансія на територію України посприяла збільшенню обсягу роботи й для цього роду військ. Військова служба для жінок стала мати більш напружений характер. Оскільки для військових у період особливого стану робочий час $€$ ненормованим, жінки вимушені поступатись багатьма цінностями свого життя: це сімейні цінності, увага дітям, батькам, собі тощо. Ураховуючи те, що більшість цих жінок $є$ дружинами військових чоловіків (багато чоловіків несуть свою службу в зоні бойових дій), на їхні плечі ліг тягар великої відповідальності.

Від самого початку бойових дій весь склад Збройних Сил був переведений на казармене положення на тривалий період часу, до сьогодні робочий графік військового залишається доволі напруженим: бойові чергування, несення служби у добових нарядах, майже безперервні військові навчання, що включають у себе переміщення в інші райони дислокації. А це постійний відрив від сім'ї, дітей, домівки. Окремо потрібно звернути свою увагу й на жінок - медичних працівників ВМКЦ м. Вінниці, які в повному складі надавали допомогу саме в зоні бойових дій. Такий режим життя не може не позначатись на здоров'ї та психіці людини. Як наслідок, було виявлено підвищений рівень тривожності й нейротизму.

У нашій роботі було використано методики, які призначені для оцінки особистісної та реактивної тривожності: опитувальник Спілбергера - Ханіна; особистісний опитувальник Айзенка, який служить для вимірювання рівня екстраверсії-інтроверсії, стабільності-нейротизму і психотизму; тест життєстійкості за методикою С. Мадді за адаптацією Д. А. Леонтьєва, який призначений для вимірювання життєстійкості особистості.

За допомогою опитувальника Спілбергера - Ханіна було проведено дослідження оцінки реактивної та особистісної тривожності у чоловіків та жіноквійськовослужбовців. Із поданих результатів можна стверджувати, що жінки більш схильні до вияву високого рівня реактивної тривожності.

Повертаючись до досліджень, які були проведені один рік тому, можна дійти висновку, що рівень тривожності значно знизився. Реактивна: серед жінок майже на $22 \%$, серед чоловіків - на $6 \%$; особистісна: серед жі- 
нок майже на $36 \%$, серед чоловіків на $3 \%$. Потрібно зазначити відчутну різницю у зміні тривожності серед жінок.

У попередньому дослідженні кількість жінок, що виявили одночасно реактивну й особистісну тривожність, становила 40,09\% (дев'ять осіб), у наявному цей показник значно зменшився - 18,18\% (чотири особи). Жінки, які виявили високі показники лише за особистісною тривожністю, становили 22,72\% (п'ять осіб), наразі 9,09\% (дві особи), та лише за реактивною - 4,54 \% (одна особа) у даному дослідженні. У чоловіків ці показники також різняться із тенденцією до зниження, але беручи до уваги, що контингент опитуваних чоловіків різниться, достовірність цих змін не може бути доволі об'єктивною.

В особистих бесідах на питання, що спричинило зниження тривоги, серед жінок були отримані такі відповіді: "Втягнулись", "А що толку постійно переживати?". Доволі вагомим стимулом послужило підвищення фінансового забезпечення та підкріплення останнім часом авторитета й популярності військових серед населення.

Особистісний опитувальник Айзенка EPQ призначений для вивчення індивідуально-психологічних рис особистості з метою діагностики ступеня вираженості властивостей, висунених як істотні компоненти особистості: нейротизм, екстра-інтроверсія і психотизм.

Чим вищий рівень екстраверсії людини і нижчий рівень нейротизму (протилежного полюсу емоційної стійкості), тим вище рівень суб'єктивного благополуччя [7]. Такий показник було виявлено у одної жінки (4,54 \%) та у шести чоловіків $(31,57 \%)$. Це майже повністю збігається з попередніми дослідженнями. При інтровертованих виявах і високому нейротизмі доцільно звернути увагу на присутність стану тривоги та реактивної депресії. Такі показники присутні у двох жінок $(9,09 \%)$ та відсутні у чоловіків (порівняно з попереднім дослідженням такі показники були взагалі відсутні).

Отже, беручи до уваги показники з обох досліджень та враховуючи деяке розходження в особах опитуваних, дозволимо собі дійти висновку, що великої відмінності в показниках не виявлено. Тобто згідно з опитувальником Айзенка, значних змін не відслідковується.

У дослідженні ми також використали матричну типологію особистостей за методикою EPQ Г. Айзенка (за Г.В.Суходольским). За допомогою даної матриці можливо визначити належність людини до одного із дев'яти типів особистості, використовуючи поєднання ступеня вираженості екстраверсії та нейротизму.

Кожному типу особистості відповідають такі зовнішні вияви: холеричний (X), холерично-сангвінічний (XC), сангвінічний $(\mathrm{C})$, сангвінічно-флегматичний (СФ), флегматичний (Ф), фрлегматично-меланхолійний (ФМ), меланхолійний (M), меланхолійно-холеричний (MX) та нормальний тип $(\mathrm{H})$.

Ураховуючи ці показники, доцільно зробити висновок, що найстабільнішими можна вважати респондентів, які виявляють сангвінічно-фрлегматичні, сангвінічні, флегматичні й нормальні вияви за даною шкалою. Найбільш нестабільнішими - меланхолійні та меланхолійно-холеричні риси, у яких також завжди високий рівень нейротизму. Сангвінічні, холеричні та холерично-сангвінічні вияви мають особистості з явно вираженою екстраверсією. Особи, які мають меланхолійний тип темпераменту, є інтровертами, а меланхолійно-холеричні - амбівертами.

Серед жінок узагалі не було виявлено осіб із фрлегматичними або сангвінічно-фрлегматичними рисами. Серед чоловіків таких осіб три (15,78 \%), вони також не $€$ яскраво вираженими екстравертами, їхній темперамент можна описати як амбівертність.

Одним із фракторів стресостійкості $є$ вияви особистістю фрлегматичних, нормальних, сангвінічних та сангвінічно-флегматичних рис темпераменту. Меншу стресостійкість виявляють особистості з меланхолійними та меланхолійно-холеричними рисами темпераменту. Отже, темперамент впливає на формування психологічної адаптації, тому доцільно враховувати вияви основних його рис. Він може служити в розробці індивідуально-реабілітаційних програм.

Тест життєстійкості за методикою С. Мадді є адаптацію Д. А. Леонтьєвим опитувальника Hardiness Survey.

Порівняно з попереднім дослідженням відслідковується тенденція до зниження показників за всіма компонентама життєстійкості серед чоловіків, та підвищення всіх показників у жінок. Показник із залучення у чоловіків знизився на $26,78 \%$, у той час як у жінок він виріс на 9,07\%; показник за контролем у чоловіків знизився на 5,73\%, у жінок виріс на 13,63\%; показник прийняття ризику у чоловіків знизився на $11,91 \%$, у жінок виріс на $22,71 \%$; показник життестійкості у чоловіків знизився на $11 \%$, у жінок підвищився на $22,72 \%$. У жінок також із попереднього дослідження показник життєстійкості у 18,18 \% (чотри особи) виріс до 4,54 \% (одна особа).

Згідно $з$ отриманими результатами можна зробити висновок, що жінки мобілізувались, почали брати відповідальність за своє життя, стали більш упевненими, усвідомленими. Підвищення за показником залученості у жінок указує на більшу включеність у свою професію, у те, чим вона займається. Це також спостерігалось під час особистих бесід. Потрібно вказати, що жінки виглядають більш спокійними та впевненими у своїх діях. На питання, із чим вони пов'язують ці зміни, були отримані відповіді, що військовослужбовці-жінки відчувають більшу стабільність у своєму житті, тоді як рік тому такого відчуття у них не було. Беручи до уваги навіть зростання відлучень від домівки та сім'ї, часті відрядження й військові навчання, добові наряди та бойові чергування, жінки відчувають себе більш впевнено, ніж торік.

В особистих бесідах із чоловіками відслідковуються явні песимістичні настрої порівняно з настроями рік тому. Відчутно фракт розчарування, недовіри до керівництва держави, вищого командування. Економічний спад у країні також сильно впливає на настрій військовослужбовців. Чоловік - це захисник родини, який відчуває відповідальність за неї. В умовах нестабільності й невпевненості часто звучали розмови про безнадійність, даремність усього, безперспективність. Навіть в умовах бойових дій часто підкреслювалось, що заборона стріляти у відповідь на провокації ворога доволі сильно впливає на психічний стан воїнів.

Але попри зниження компонентів життєстійкості серед опитуваних чоловіків загалом рівень цих показників вищий, ніж серед жінок. Що також підтверджує попередні припущення щодо більшої вразливості жіночої психіки і меншої стресостійкості серед жінок. Причиною може бути і присутній сексизм в армійських рядах з боку чоловіків, про що останнім часом доволі часто згадується, і дискримінація жінки як рівного воїна. Цей фактор не може не відображатись на впевненості жінки-військовослужбовця, її самооцінці. Адже командири й начальники, переважною більшістю, - це чоловіки, які не завжди уміють спілкуватись із жінками, знають гендерні відмінності між статями, володіють знаннями у сфері відмінностей між жіночою та чоловічою психікою та вміють ефективно керувати жіночими колективами

Жінка є більш вразливою внаслідок того, що на її плечах попри службових обов'язків лежить відповідальність і за сім'ю, дітей, батьків, домівку. Іноді їй дуже тяжко перемкнутись від побутових проблем на службові, вона може відчувати недостатню підтримку. Одним із аргументів, яким апелюють командири проти жінки в армії, є народження дітей, лікарняні та відпустки по догляду за дітьми. Це часто руйнує стабільність у графіках чергувань та нарядів. Унаслідок цього жінка часто відчуває своє приниження, адже в першу чергу вона все-таки мати й жінка і може ставити сімейні цінності вище службових, у той час як чоловіки доволі часто цього не розуміють й чинять по-іншому. Усі ці незручно- 
сті бувають для чоловіка несподіваними, неочікуваними, вимушують перебудовувати свої плани, що не завжди сприймається позитивно й не всі начальники вміють поводитись тактовно та ставитись лояльно до таких особливостей. Високий рівень серед військових жінок матерів-одиначок.

Але справедливо буде зазначити, що останнім часом жінки виявляють себе як особистості, які можуть швидко пристосовуватись до різних незручностей стосовно побуту. Доказом цього можуть бути часті виїзди в зону бойових дій або проведення військових навчань. Із особистих бесід стало відомо, що ті незручності, які виникають у несприятливих побутових умовах, жінки також переносять стійко та із розумінням до них ставляться. Тому ми вважаємо доцільним проводити роз'яснювальну роботу з командирами та військовими начальниками із запобігання сексизму в Збройних Силах України.

Висновки. В результаті проведеного нами дослідження було виявлено особливості перебігу емоційнопсихічних розладів у жінок та чоловіків, а саме: визначено, що рівень тривожності й нейротизму у групі жінок значно перевищує чоловіків; а показники за компонентами життєстійкості у чоловіків значно вищі, ніж у жінок, що говорить про їх взаємний вплив: чим вищий рівень тривожності та нейротизму, тим нижчий рівень життєстійкості. Також це свідчить про кращі адаптивні можливості чоловіків та їхню скорішу пристосовуваність до стресогенних ситуацій.

У результаті дослідження було виявлено фракти зниження реактивної та особистісної тривожності у жінок і чоловіків. У жінок підвищились показники за компонентами життєстійкості; у чоловіків ці компоненти знизились, що говорить про зниження позитивних емоційних настроїв серед чоловіків та підвищення рівнів стресостійкості серед жінок. Також у жінок було виявлено зниження високих показників за шкалою екстраверсії, що свідчить про певну "закритість" і стриманість у виявах емоційно-почуттєвої сфери. Також нами була виявлена тенденція впливу зниження тривожності на підвищення життєстійкості.

Перспективи подальших досліджень. Обрана нами тема $є$ доволі перспективною й потребує подальшої розробки. Ураховуючи отримані нами результати, є доцільно їх використовувати у подальших розробках реабілітаційних програм для військовослужбовців, які мають досвід перебування у психотравмуючих ситуаціях, розлади адаптації, психічні травми та знижений рівень стресостійкості 3 метою покращення їх ресоціалізації в сучасному суспільстві. Дане дослідження доцільно використовувати також у розробці програм із питань роботи 3 жінками-військовослужбовцями для їх соціалізації у військових колективах.

Список використаних джерел

1. Андрощук О. Ю. Гендерний аспект у військовій сфері / О. Ю. Андрощук, О. Л. Луцький // Вісн. НАДПСУ. - Хмельницький, 2011. - №1. - 7 с

2. Бурчак О.І. Гендерні особливості особистісних властивостей військовослужбовців : дипломна робота на здобут. освітньо-кваліфікац. рівня "Магістр", спец. "Психологія" / ЖДУ ім. І. Франка / О.І.Бурчак. Житомир, 2014. - 46 с

3. Гендерні особливості стресу [Електронний ресурс]. - Режим доступу: http://ua-referat.com

4. Корчемний П. А. Військова психологія: методологія, теорія, практика [Електронний ресурс]/П. А. Корчемний. - Режим доступу: http://medbib.in.ua/boevoy-stress-ego-psihologicheskie-38893.html.

5. Обозов Н. Н. Межличностные отношения / Н. Н. Обозов. - Л. : ЛГУ, 1979. -160

6. Топоренко О. Ю. Стратегії інтеграції жінки у зСУ. Гендерні студії в сучасній Україні : матеріали студ. наук.-практ. конф. (12-13 березня 2015 р.) : зб. наук. ст. / гол. ред. С. О. Філоненко. - Бердянськ : БДПУ, 2015. - $96 \mathrm{c}$

7. Французова К. Психологічна травма і шляхи її подолання [Електронний ресурс]/К. Французова. - Режим доступу: http://upsihologa.com.ua/ Psihologichna_travma_i_shlya-frantsuaza.html.

Reference

1. Androshchuk O. Yu. Hendernyi aspekt $u$ viiskovii sferi/ O. Yu. Androshchuk, O. L. Lutskyi // Visnyk NADPSU. - Khmelnytskyi, 2011. - № 1. - $7 \mathrm{~s}$.

2. Burchak O. I. Henderni osoblyvosti osobystisnykh vlastyvostei viiskovosluzhbovtsiv: dyplomna robota ... "mahistr": spets. 8.03010203"Psykholohiia" ZhDU im. I. Franka / O. I. Burchak. - Zhytomyr, 2014. - 46 s.

3. Henderni osoblyvosti stresu [Elektronnyi resurs] / Sposib dostupu: http://ua-referat.com

4. Korchemnyi P. A. Viiskova psykholohiia: metodolohiia, teoriia, praktyka [Elektronnyi resurs] / P. A. Korchemnyi // Sposib dostupu: http://medbib.in.ua/boevoy-stress-ego-psihologicheskie-38893.htm

5. Obozov N. N. Mezhlichnostnye otnosheniia / N. N. Obozov. - L. : LGU, 1979. $-160 \mathrm{~s}$.

6. Toporenko O. Yu. Stratehii intehratsii zhinky u ZSU. Henderni studii v suchasnii Ukraini : materialy stud. nauk.-prakt. konf. (12-13 bereznia 2015 r.) : zb. nauk. st. / [hol. red. S. O. Filonenko]. - Berdiansk: BDPU, 2015. $-96 \mathrm{~s}$.

7. Frantsuzova K. Psykholohichna travma i shliakhy yii podolannia [Elektronnyi resurs] / K. Frantsuzova // Sposib dostupu: http://upsihologa.com.ua/ Psihologichna travma i shlya-frantsuaza.html

Надійшла до редколегії 03.11.18

М. Прищепа, психолог

Вооруженные силы Украины

\section{ГЕНДЕРНЫЕ ОСОБЕННОСТИ ПЕРЕЖИВАНИЯ ПСИХОТРАВМИРУЮЩИХ СИТУАЦИЙ ВОЕННОСЛУЖАЩИМИ В ХОДЕ РЕСОЦИАЛИЗАЦИИ В ПОСТТРАВМАТИЧЕСКОМ ПЕРИОДЕ}

Статья посвящена анализу различий в восприятии стрессовых и психотравмирующих ситуаций и их влияния на личностные изменения между мужчинами и женщинами, которые принимали участие в боевых действиях и которые находились вне зоны военного конфликта в период ресоциализации.

Ключевые слова: военнослужащий, посттравматическое стрессовое расстройство, психотравмирующая ситуация, стрессоустойчивость, боевые действия.

M. Pryshchepa, psychologist

Ukrainian Army

\section{GENDER PECULIARITIES OF PSYCHO-TRAUMATIC SITUATIONS EXPERIENCING BY THE MILITARY MEN IN THE PROCESS OF THEIR RESOCIALIZATION DURING THE POST-TRAUMATIC PERIOD}

The article is devoted to the analysis of differences in the perception of stressful and psycho-traumatic situations and their influence on personality changes of men and women who took part in the hostilities and who were outside the zone of military conflict during the period of resocialization. The author indicates the features of the socio-political state and those realities that cause a negative impact on the psychological state of soldiers. The reasons for the relevance of the topic of re-socialization of military personnel who have survived traumatic situations are given, and the thesis is expressed on the difference in such a process depending on the gender of the military personnel. The authors' previous experiences on the topics of gender, levels of psychological traumatic situations and their experiences are outlined. Little studied moments have been identified, such as the difference in the perception of stressful and psycho-traumatic situations and their effect on personality changes in men and women who took part in the hostilities and who were outside the zone of military conflict. Recommendations are given on the successful resocialization of servicemen who survived traumatic situations and who were in the combat zone for a certain time. Information is added about the neuropsychological differences between men and women that affect their strategies for experiencing a traumatic situation. The research sample and its features are described, the limitations in the selection and use of research tools are explained. The results are given by quantitative and qualitative methods for which there is a gender difference. Information on the results of the study was summarized, during which the characteristics of the course of emotional and mental disorders in women and men were revealed in the sample, and facts of a decrease in reactive and personal anxiety in military personnel of various genders were revealed.

Keywords: military, psycho-traumatic stress disorder, psycho-traumatic situation, stress tolerance, combat missions. 